\title{
Asbestos manufacturing plants in Poland
}

\begin{abstract}
The unique set of physical and chemical properties of asbestos has led to its many industrial applications, such as roof coverings, textiles, rope, cord and yarn, paper, friction and composition materials, household product, acid-resistant filters, packing, insulation, and certain types of lagging, amongst others. In Poland asbestos-containing products were manufactured from raw materials imported mainly from the former Soviet Union, with production launched at the beginning of 20th century. According to Annex 4 to the Act of 19 June 1997 on the prohibition of the use of asbestos-containing products, there were 28 asbestos manufacturing plants in Poland located in 11 provinces throughout the country. The current survey was undertaken to enable asbestos manufacturing plants to be arranged, described and divided in order to contribute to further surveys.
\end{abstract}

Keywords

Asbestos • asbestos manufacturing • asbestos plants in Poland

(C) University of Warsaw - Faculty of Geography and Regional Studies

\author{
Ewa Wilk1 \\ Małgorzata Krówczyńska² \\ Bogdan Zagajewski ${ }^{3}$ \\ 'Department of Geoinformatics and Remote Sensing \\ Faculty of Geography and Regional Studies \\ University of Warsaw; \\ WGS84 Polska Sp. z 0.o., Milanówek, Poland \\ e-mail: ewa.wilk@student.uw.edu.pl \\ 2Department of Geoinformatics and Remote Sensing \\ Faculty of Geography and Regional Studies \\ University of Warsaw; \\ WGS84 Polska Sp. z o.o., Milanówek, Poland \\ e-mail:mkrowczynska@uw.edu.pl \\ ${ }^{3}$ Department of Geoinformatics and Remote Sensing \\ Faculty of Geography and Regional Studies \\ University of Warsaw \\ e-mail: bogdan@uw.edu.pl \\ Received: 27 December 2013 \\ Accepted: 12 May 2014
}

\section{Introduction}

The term asbestos denotes chrysotile (white asbestos), amosite (brown asbestos), crocidolite (blue asbestos), tremolite, anthophyllite and actinolite. Asbestos fibres are tensile, strong, resistant to thermal and chemical degradation, flexible, have a high electrical resistance and can be woven (Hendry 1965; Ross et al. 2007). Taking into account asbestos fibre structure allows division into two groups: serpentines and amphiboles (Ross et al. 2007). Chrysotile, the serpentine mineral, crystallizes as rolled up sheets. The double-chain structure is specific for amphiboles. Different kinds of amphiboles are distinguishable by the amount of sodium, magnesium, calcium and iron that they contain. Serpentine and amphibole minerals can have fibrous or non-fibrous structures. The fibrous type is known as asbestos (Virta 2001). The amphibole minerals can occur in a form that is not poly filamentous and therefore they are not classified as asbestos (Ross et al. 2007). Despite the common occurrence of asbestos, there is a crucial difference between occurrences and commercial deposits. In terms of production of all types of asbestos, North America has been the leader, followed by Europe, Africa, Asia, Australia, and South America. Chrysotile, also known as "white asbestos" (Thomson \& Mason 2002), accounts for 93 percent of total asbestos production. The main recipient of chrysotile is the asbestos cement industry. The combination of asbestos fibres with cement, silica and water has led to the development of a variety of products and applications. Chrysotile has been used in the manufacture of roof coverings (flat and corrugated sheets), pipes, and floors (Dunnigan 1993). Depending on the product, the weight proportion of asbestos to cement may vary from 15 to 90 percent (Virta 2002). Chrysotile also has many different industrial applications, being the component of textiles, rope, cord and yarn, paper, friction and composition materials, household products, etc. (Alleman \& Mossman 1997). Amphiboles have also been used in the industry. Crocidolite, also known as "blue asbestos", has been used mainly in the manufacture of asbestos cement products (Thompson \& Mason 2002), as well as the manufacturing of acid-resistant filters, packing, insulation, and certain types of lagging. Tremolite and actinolite are of less importance from an economic point of view. They are exploited in the chemical industry as filter mediums and also for special uses in the filtration field. Anthophyllite has been used in the chemical industry, as a filler in the rubber and plastic industries and in various adhesives and cements. Use of amosite ("brown asbestos") was of great importance in the insulation field in the manufacture of pipes and boilers (Hendry 1965).

Commercial production of asbestos began in Italy around 1850 with cloth and paper making. In 1880 a breakthrough in production took place due to the development of asbestos mining in Canada and South Africa. It reduced costs and therefore reinforced the manufacture of asbestos products. Soon mining and production of asbestos in the United States, Italy and Russia was expanded (Lee \& Selikoff 1979). Asbestos usage was at an extremely low level when compared with $20^{\text {th }}$ century production. Along with the progress of industrialization, new uses of asbestos were implemented in order to benefit from the strength, heat resistance and flexibility of asbestos fibres (Virta 2006). In the 1930s Canada was the major asbestos producer. Production increased slowly until the beginning of World War II. During the war there was a notable decline in production, with the exception 
MISCELLANEA GEOGRAPHICA - REGIONAL STUDIES ON DEVELOPMENT

Vol. 18 • No. 2 • 2014 • pp. 53-58 • ISSN: 2084-6118 • DOI: 10.2478/mgrsd-2014-0022

Table 1. Asbestos product applications (Thompson \& Mason 2002, Siuta 2001, Łuniewski \& Łuniewski 2009, Brzozowski \& Obmiński 2004, ed. Dyczek 2005)

\begin{tabular}{|c|c|}
\hline Type of asbestos products & Example of uses \\
\hline Asbestos-cement & $\begin{array}{l}\text { Flat and corrugated sheets, floors and walls, burners, sewer pipes, water pipes, covering for } \\
\text { furnaces, fire-retardant board made of asbestos-containing products („sokalit”, „PYRAL”), } \\
\text { plaster containing asbestos and fire protection covering and as thermal insulation (fire } \\
\text { resistant) and acoustic insulation in public buildings using plaster containing asbestos and fire- } \\
\text { retardant asbestos coatings }\end{array}$ \\
\hline Asbestos rope and cord & $\begin{array}{c}\text { Fire mats, gaskets, pipe and joint packing, covering for electric fires, wicks, duct tape, } \\
\text { insulating fabrics, cotton and yarn }\end{array}$ \\
\hline Asbestos cloth & $\begin{array}{l}\text { Brake lining, clutch facings, theatre curtains and scenery, sheet packing, firemen's clothing, } \\
\text { fireproof gloves, welding equipment, filter pads, protective, fire-resistant asbestos-weave } \\
\text { blankets, asbestos tape and ropes }\end{array}$ \\
\hline Composition materials & $\begin{array}{c}\text { Asbestos-rubber sealant („POLONIT”, „Gambit”), binders for plasters, hard rubber and stucco, } \\
\text { electrical insulation, laboratory uses, plates and seals for the valve connections leading to } \\
\text { high performance water or steam, inert gas and active solutions of inorganic and organic salts, } \\
\text { seals, insulators }\end{array}$ \\
\hline Asbestos paper & $\begin{array}{c}\text { Roofing paper, pipe covering, seals, electrical equipment, flooring paper, cartons, steam } \\
\text { equipment }\end{array}$ \\
\hline Other & Hair dryers, pot holders, ironing pads, artificial fireplaces, baby bibs, paints, jewellery \\
\hline
\end{tabular}

of Canada and South Africa. After World War II, global asbestos production increased again. By 1958, asbestos was used in about 3,000 applications. During the first half of the $20^{\text {th }}$ century Canada remained the major asbestos producer, and by 1980, Russia had become the largest manufacturer of asbestos products, followed by Brazil, China, South Africa, and Zimbabwe. Current production has decreased in all major producing countries except China. The leading producer of asbestos worldwide is Russia, followed by China, Kazakhstan, Brazil, Canada, Zimbabwe, and Colombia, who together manufacture more than $90 \%$ of the entire global production nowadays (Virta 2002), with total annual production of asbestos-containing products exceeding 2 million tons (Asbestos. 2006 Mineral Yearbook 2007, Asbestos. 2012 Mineral Yearbook 2013). The use and the production of asbestos is now banned in 52 countries, including all European Union member countries, and safer products have replaced many that were once made with asbestos (Collegium Ramazzini 2010).

The purpose of the study is to present the asbestos production in Poland in terms of manufacturing plants, types of asbestos used and kinds of asbestos-containing products made.

\section{Research objective}

In Poland asbestos-containing products were manufactured from raw materials imported from the former Soviet Union (Russia, Lithuania, Kazakhstan, and Belarus), as well as from Canada, Italy, Australia and the UK. Poland does not have natural resources of asbestos mined on an industrial scale. According to Chief Statistical Office data for the period 1955-1995, the import of asbestos into the country amounted to more than 2,000,000 tons. It is estimated that more than $75 \%$ of asbestos imported into the country is used for the fabrication of asbestos-cement products, and more than 500,000 tons as raw material for the manufacture of other products containing asbestos (Siuta 2001).

The production of asbestos-containing products was launched in 1907 at the Cracow Eternit Plant in Cracow. Two years later, production was initiated in Lublin at the Lublin Eternit Plant. In the 1930s, the Chrzanów Eternit Plant in Górka launched asbestos manufacture. In the 1950s, asbestos production began at the Zawiercie Eternit Plant in Ogrodzieniec, the Asbestos cement Products Plant in Szczucin and the Asbestos-Cement Products
Plant in Wierzbica. At the end of the 1960s, the production of corrugated and flat sheets as well as cladding panels began at the Asbestos Cement Plant in Trzemeszno. In the early 1970s, the production of corrugated and autoclaved sheets was launched at the plant in Małkinia.

According to Polish legal regulations, an asbestos-containing product is a product which contains $0.1 \%$ or more of asbestos (Act of 19 June 1997). Manufactured asbestos-containing products can be divided into the following groups:

- loose mixture of different fibres, and mixtures of pure asbestos fibres with cement or plaster;

- composites of asbestos-related inorganic (cement) or organic (plastics, bitumen) binder;

- asbestos textiles (yarn, ribbons, lace, fabrics, clothes, etc.).

Asbestos-containing products have been used in Poland in many branches of the economy. A sample of asbestos applications is presented in Table 1.

The aim of the study was to present the locations of the asbestos manufacturing plants in Poland, types of asbestos used and kinds of asbestos-containing products manufactured. The study consisted of three stages:

1. Preparatory stage, including literature review, development of research questionnaires.

2. Data collection, including questionnaire survey supported by field visits.

3. In-depth analysis, synthesis and result formulation.

In 1997, Poland introduced a ban on the production of asbestos-containing products. According to its provisions, the production of asbestos products was terminated by 28 September 1998 , and a ban on the marketing of asbestos and products containing asbestos was introduced after 28 March 1999 (Act of 19 June 1997, Ordinance of Minister of Economy of 13 December 2010).

\section{Research methods}

All asbestos manufacturing plants listed in Annex 4 to the Act of 19 June 1997 on the prohibition of the use of asbestoscontaining products formed the basis for the study covering the following plants: 
1. Fabryka Okładzin Ciernych "FOMAR ROULUNDS" S.A. in Marki near Warsaw with its cooperators.

2. Przedsiębiorstwo Państwowe "GAMBIT" Zakład Pracy Chronionej in Lubawka.

3. Wytwórnia Uszczelek "MORPAK" Sp. z o.o. in Gdańsk.

4. Fabryka Odzieży i Tkanin Żaroodpornych "IZO-TERM" in Gryfów Śląski.

5. Zakłady Wyrobów Uszczelniających i Termoizolacyjnych POLONIT Sp. z o.o. in Łódź.

6. Mazowieckie Przedsiębiorstwo Materiałów Izolacji Budowlanej "Izolacja" in Małkinia.

7. Pruszkowskie Zakłady Materiałów Izolacyjnych in Pruszków.

8. Lubelskie Zakłady Eternitu in Lublin.

9. Zakład Produkcji Płytek Cementowo-Azbestowych in Końskowola near Puławy.

10. Przedsiębiorstwo Materiałów Izolacji Budowlanej "IZOLACJA" in Jarocin.

11. Zakłady Wyrobów Azbestowo-Cementowych "COBRPIB" in Katowice.

12. Centralny Ośrodek Badawczo-Rozwojowy Przemysłu Izolacji Budowlanej at the Katowice Branch in Pruszków.

13. BEMA Fabryka Płyt Filtracyjnych i Tektury in Pilchowice.

14. "Dachy Szczucińskie" Sp. z o.o. in Szczucin.

15. Przedsiębiorstwo Produkcyjno-Handlowo-Usługowe "IZOPOL" S.A. in Trzemeszno.

16. Przedsiębiorstwo Materiałów Izolacji Budowlanej "IZOLACJA" in Ogrodzieniec.

17. Fabryka Styropianu i Wyrobów Pokryciowych "Izolacja" PP in Wierzbica near Radom.

18. "POLIFARB-CIESZYN" S.A. in Wrocław.

19. PPHU HAMEX in Wrocław.

20. Kombinat Budowlany in Włocławek.

21. Rolnicza Spółdzielnia Produkcyjna in Parczew.

22. Przedsiębiorstwo Produkcyjno-Wdrożeniowe "Polinova" Sp. z o.o. in Katowice - Branch in Trzebinia.

23. Metsa Tissue S.A. in Konstancin-Jeziorna.

24. Zakłady Chemiczne i Tworzyw Sztucznych Boryszew S.A. in Sochaczew.

25. KONIMPEX Sp. z o.o. Konin, Branch in Sokółka.

26. Wytwórnia Materiałów Izolacyjnych AzbestowoCementowych S.C. in Żelechy, Piątnica.

27. Wytwórnia Uszczelek "PZL MORPAK" Branch in Łapino.

28. PILKINGTON POLSKA in Sandomierz.

The study of the asbestos plants was divided into stages with tasks to perform. During the first stage an assumption was made that all asbestos manufacturing plants are listed in Annex 4 to the Act of 19 June 1997 on the prohibition of the use of asbestoscontaining products. The subsequent task in the first stage was to develop research questionnaires and tailor them in order to obtain the required data for further analysis. The inquiry comprised the following issues: legal and organizational matters, data on historical production, current activities, and the plants' asbestos abatement, including the use of asbestos-containing products.

During the second stage of the study the data collection process was executed. The first task was to determine the current locations (address data). This task was of a great importance for the study due to the administrative changes which have taken place in Poland over the years. After determining the address data, questionnaires were distributed to all manufacturing plants and a thorough examination of source materials in the archives was also conducted. They were supported by the results of the literature review and other available data sources. Subsequently, the plants' legal status was verified with files derived from the National Court Register and the District Court.
For those plants where the responses given in the questionnaire survey were deficient, corrective actions have been taken. These actions involved the redistribution of questionnaires, telephone interviews and field visits to carry out in-depth interviews with the head of the entity or an authorized person. On-site visits were performed in all manufacturing plant locations. The main objective of performing on-site visits was to obtain an objective assurance as to the present condition of the asbestos manufacturing plants, including the usage of asbestoscontaining products, and the preparation of photographic documentation of each plant.

The data submitted by asbestos manufacturing plants were verified at a later stage with the Marshal Offices, as the entities responsible for keeping a register of the use of asbestoscontaining products. The verification process was executed with an additional questionnaire comprising the same attributes as requested from manufacturing plant owners. The purpose of this action was to check the comprehensiveness of acquired data, with particular attention paid to filling the obligations in the framework of the law.

During the third stage of the study, in-depth analyses were undertaken. The basis for the diagnosis of the status quo were the following data: questionnaires completed and returned by the current owners of former manufacturing plants, results of field visits including address data verification, interviews conducted, use of asbestos-containing products, and photographic documentation. Based on the data collected, GIS analyses were performed using ArcGIS 10 software.

\section{Results}

Plants listed in Annex 4 to the Act of 19 June 1997 banning the use of asbestos-containing products are located in 11 provinces throughout the country: Lower Silesia, Kuyavia and Pomerania, Lubelskie Region, Łódzkie Region, Lesser Poland, Mazovia, Podlaskie Region, Pomerania, Silesia, Greater Poland, and Świętokrzyskie Region. The details of asbestos manufacturing plants gathered through the preparation of study results are presented in Table 2.

The undertaken survey enabled asbestos manufacturing plants to be arranged, described and divided. Based on the survey results gathered in Table 2 and the asbestos-containing products division shown in Table 1, asbestos manufacturing plants were assigned to six groups, presented in Fig. 1. It is noteworthy that 10 out of all the asbestos manufacturing plants manufactured asbestos-cement roofing and 6 plants did not undertake asbestos manufacturing process.

The distribution of the plants that manufactured asbestoscement products used in construction is of particular importance in our analysis. Asbestos-cement roofing and pipes account for $90 \%$ of asbestos used in the world today (Collegium Ramazzini 2010). The amount of asbestos-cement roofing in gminas (the lowest level of territorial division in Poland) as of the end of 2013 in relation to locations of asbestos manufacturing plants is presented on Fig. 2.

Relatively high concentrations of asbestos products are observed in the proximity of asbestos roofing manufacturing plants, i.e. Małkinia, Lublin, Wierzbica, Szczucin, Trzebinia, Ogrodzieniec Trzemeszno. In gminas where the plants were located, as well as in their vicinities, the amount of asbestos in relation to the surface area of the gmina is greater than 50 tons $/ \mathrm{km}^{2}$. The research undertaken allows for the organization of acquired historical data on production as well as establishing directions for further research, in particular in terms of a geostatistical survey of the determinants influencing the amount of asbestos-cement roofing in Poland. 
MISCELLANEA GEOGRAPHICA - REGIONAL STUDIES ON DEVELOPMENT

Vol. 18 • No. 2 - 2014 • pp. 53-58 • ISSN: 2084-6118 • DOI: 10.2478/mgrsd-2014-0022

Table 2. Details of asbestos manufacturing plants in Poland

\begin{tabular}{|c|c|c|c|c|c|}
\hline No. & Name of plant & $\begin{array}{l}\text { Location of } \\
\text { plant }\end{array}$ & Products manufactured & $\begin{array}{l}\text { Year of } \\
\text { commencement } \\
\text { of production }\end{array}$ & $\begin{array}{l}\text { Year of } \\
\text { completion of } \\
\text { production }\end{array}$ \\
\hline 1 & $\begin{array}{l}\text { Fabryka Okładzin Ciernych } \\
\text { "FOMAR ROULUNDS" S.A. }\end{array}$ & Marki & $\begin{array}{l}\text { friction linings, drums and discs } \\
\text { containing asbestos }\end{array}$ & 1956 & 1995 \\
\hline 2 & $\begin{array}{c}\text { Przedsiębiorstwo } \\
\text { Państwowe "GAMBIT" } \\
\text { Zakład Pracy Chronionej }\end{array}$ & Lubawka & $\begin{array}{l}\text { insulating cardboard, tape, brakes } \\
\text { and seals }\end{array}$ & 1962 & 1999 \\
\hline 3 & $\begin{array}{l}\text { Wytwórnia Uszczelek } \\
\text { "MORPAK" Sp. z o.o. }\end{array}$ & Gdańsk & seals and asbestos-copper rings & 1946 & 1996 \\
\hline 4 & $\begin{array}{l}\text { Fabryka Odzieży i Tkanin } \\
\text { Żaroodpornych "IZO-TERM" }\end{array}$ & Gryfów Śląski & $\begin{array}{l}\text { asbestos suits for metallurgists, } \\
\text { mining teams and volunteer } \\
\text { firefighters, corrugated asbestos as } \\
\text { a blank for seals for the automotive } \\
\text { industry, insulating cords }\end{array}$ & 1954 & 1992 \\
\hline 5 & $\begin{array}{l}\text { Zakłady Wyrobów } \\
\text { Uszczelniających i } \\
\text { Termoizolacyjnych } \\
\text { POLONIT Sp. z o.o. }\end{array}$ & Łódź & $\begin{array}{l}\text { asbestos sealant, insulating cords, } \\
\text { sealing plates, yarn, cardboard and } \\
\text { asbestos friction }\end{array}$ & 1926 & 1997 \\
\hline 6 & $\begin{array}{c}\text { Mazowieckie } \\
\text { Przedsiębiorstwo } \\
\text { Materiałów Izolacji } \\
\text { Budowlanej “Izolacja” }\end{array}$ & Małkinia & $\begin{array}{c}\text { corrugated asbestos-cement and flat } \\
\text { sheets ("acekol" and "kolorys") and } \\
\text { ridge hinges }\end{array}$ & 1972 & 1990 \\
\hline 7 & $\begin{array}{l}\text { Pruszkowskie Zakłady } \\
\text { Materiałów Izolacyjnych }\end{array}$ & Pruszków & no asbestos products manufactured & - & - \\
\hline 8 & Lubelskie Zakłady Eternitu & Lublin & corrugated asbestos-cement sheets & 1952 & 1989 \\
\hline 9 & $\begin{array}{l}\text { Zakład Produkcji Płytek } \\
\text { Cementowo-Azbestowych }\end{array}$ & $\begin{array}{l}\text { Końskowola } \\
\text { near Puławy }\end{array}$ & asbestos-cement flat sheets ("karo") & 1976 & 1990 \\
\hline 10 & $\begin{array}{c}\text { Przedsiębiorstwo } \\
\text { Materiałów Izolacji } \\
\text { Budowlanej "IZOLACJA" }\end{array}$ & Jarocin & asphalt roofing with asbestos filler & 1963 & 1982 \\
\hline 11 & $\begin{array}{c}\text { Zakłady Wyrobów } \\
\text { Azbestowo-Cementowych } \\
\text { "COBRPIB" }\end{array}$ & Katowice & no asbestos products manufactured & - & - \\
\hline 12 & $\begin{array}{l}\text { Centralny Ośrodek } \\
\text { Badawczo-Rozwojowy } \\
\text { Przemysłu Izolacji } \\
\text { Budowlanej in Katowice }\end{array}$ & Pruszków & no asbestos products manufactured & - & - \\
\hline 13 & $\begin{array}{l}\text { BEMA Fabryka Płyt } \\
\text { Filtracyjnych i Tektury }\end{array}$ & Pilchowice & $\begin{array}{l}\text { asbestos-containing filter plates for } \\
\text { the food industry }\end{array}$ & 1962 & 1989 \\
\hline 14 & $\begin{array}{c}\text { "Dachy Szczucińskie” Sp. } \\
\text { z o.o. * }\end{array}$ & Szczucin & $\begin{array}{l}\text { corrugated asbestos-cement sheets, } \\
\text { pressure pipes and asbestos cement } \\
\text { products }\end{array}$ & 1959 & 1998 \\
\hline 15 & $\begin{array}{l}\text { Przedsiębiorstwo } \\
\text { Produkcyjno-Handlowo- } \\
\text { Usługowe "IZOPOL" S.A. }\end{array}$ & Trzemeszno & $\begin{array}{l}\text { corrugated asbestos-cement sheets } \\
\text { used in construction (type WF-6 and } \\
\text { NF-9) and ridges }\end{array}$ & 1968 & 1998 \\
\hline 16 & $\begin{array}{c}\text { Przedsiębiorstwo } \\
\text { Materiałów Izolacji } \\
\text { Budowlanej "IZOLACJA" ** }\end{array}$ & Ogrodzieniec & $\begin{array}{l}\text { corrugated asbestos-cement sheets, } \\
\text { flat sheets („karo”), flat cladding } \\
\text { panels and ridge tiles containing } \\
\text { asbestos }\end{array}$ & 1952 & 1998 \\
\hline 17 & $\begin{array}{c}\text { Fabryka Styropianu i } \\
\text { Wyrobów Pokryciowych } \\
\text { "Izolacja" PP }\end{array}$ & $\begin{array}{l}\text { Wierzbica } \\
\text { near Radom }\end{array}$ & $\begin{array}{l}\text { corrugated sheets, pipes and fittings } \\
\text { for sewerage }\end{array}$ & 1965 & 1997 \\
\hline 18 & $\begin{array}{l}\text { "POLIFARB"-CIESZYN" } \\
\text { S.A. }\end{array}$ & Wrocław & $\begin{array}{c}\text { paints and varnishes containing } \\
\text { asbestos }\end{array}$ & 1972 & 1988 \\
\hline 19 & PPHU HAMEX & Wrocław & asbestos pads and brake linings & 1973 & 1991 \\
\hline
\end{tabular}


Continued Table 2. Details of asbestos manufacturing plants in Poland

\begin{tabular}{|c|c|c|c|c|c|}
\hline No. & Name of plant & $\begin{array}{l}\text { Location of } \\
\text { plant }\end{array}$ & Products manufactured & $\begin{array}{c}\text { Year of } \\
\text { commencement } \\
\text { of production }\end{array}$ & $\begin{array}{c}\text { Year of } \\
\text { completion of } \\
\text { production }\end{array}$ \\
\hline 20 & Kombinat Budowlany & Włocławek & no asbestos products manufactured & - & - \\
\hline 21 & $\begin{array}{l}\text { Rolnicza Spółdzielnia } \\
\text { Produkcyjna }\end{array}$ & Parczew & flat asbestos cement sheets ("karo") & 1956 & 1997 \\
\hline 22 & $\begin{array}{l}\text { Przedsiębiorstwo } \\
\text { Produkcyjno-Wdrożeniowe } \\
\text { "Polinova" Sp. z o.o. }\end{array}$ & Trzebinia & corrugated asbestos-cement sheets & 1924 & 1991 \\
\hline 23 & Metsa Tissue S.A. & $\begin{array}{l}\text { Konstancin- } \\
\text { Jeziorna }\end{array}$ & asbestos cartons & 1939 & 1989 \\
\hline 24 & $\begin{array}{l}\text { Zakłady Chemiczne i } \\
\text { Tworzyw Sztucznych } \\
\text { Boryszew S.A. }\end{array}$ & Sochaczew & $\begin{array}{l}\text { floor tiles, molding plates and brake } \\
\text { pads using asbestos }\end{array}$ & 1957 & 1983 \\
\hline 25 & KONIMPEX Sp. z o.o. *** & Sokółka & no asbestos products manufactured & - & - \\
\hline 26 & $\begin{array}{l}\text { Wytwórnia Materiałów } \\
\text { Izolacyjnych Azbestowo- } \\
\text { Cementowych S.C. }\end{array}$ & $\begin{array}{l}\text { Żelechy near } \\
\text { Piątnica }\end{array}$ & $\begin{array}{l}\text { corrugated asbestos-cement sheets } \\
\text { used in construction }\end{array}$ & 1988 & 1989 \\
\hline 27 & $\begin{array}{c}\text { Wytwórnia Uszczelek "PZL } \\
\text { MORPAK" }\end{array}$ & Łapino & $\begin{array}{l}\text { asbestos-rubber paper used for the } \\
\text { production of gaskets }\end{array}$ & 1982 & 1996 \\
\hline 28 & PILKINGTON POLSKA & Sandomierz & no asbestos products manufactured & - & - \\
\hline
\end{tabular}

* This plant was the only manufacturer in the country of pressure pipes of a large diameter, for which crocidolite was used.

** Crocidolite was used in production (crocidolite is the most hazardous of all asbestos fibre types).

*** The plant was used as a loading area for asbestos imported from the territory of the former USSR.
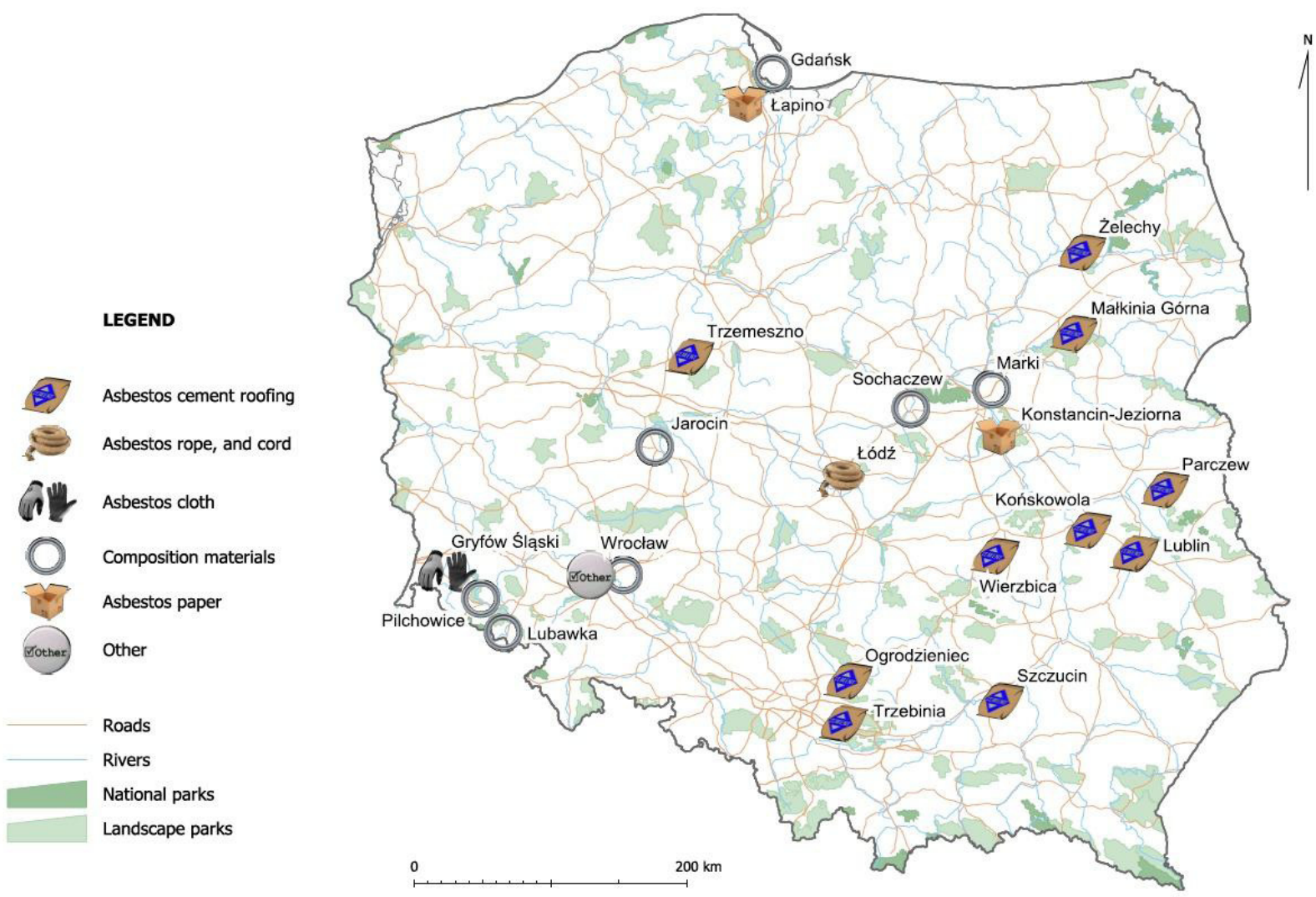

Figure 1. Type of asbestos-containing products 
LEGEND

Plants manufacturing

asbestos-cement roofing

Distance from asbestos-cement roofing manufacturing plants:

$<50 \mathrm{~km}$

$50-100 \mathrm{~km}$

$100-150 \mathrm{~km}$

Amount of asbestos-cement

roofing [tons $\left./ \mathrm{km}^{2}\right]$ :

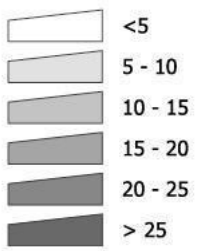

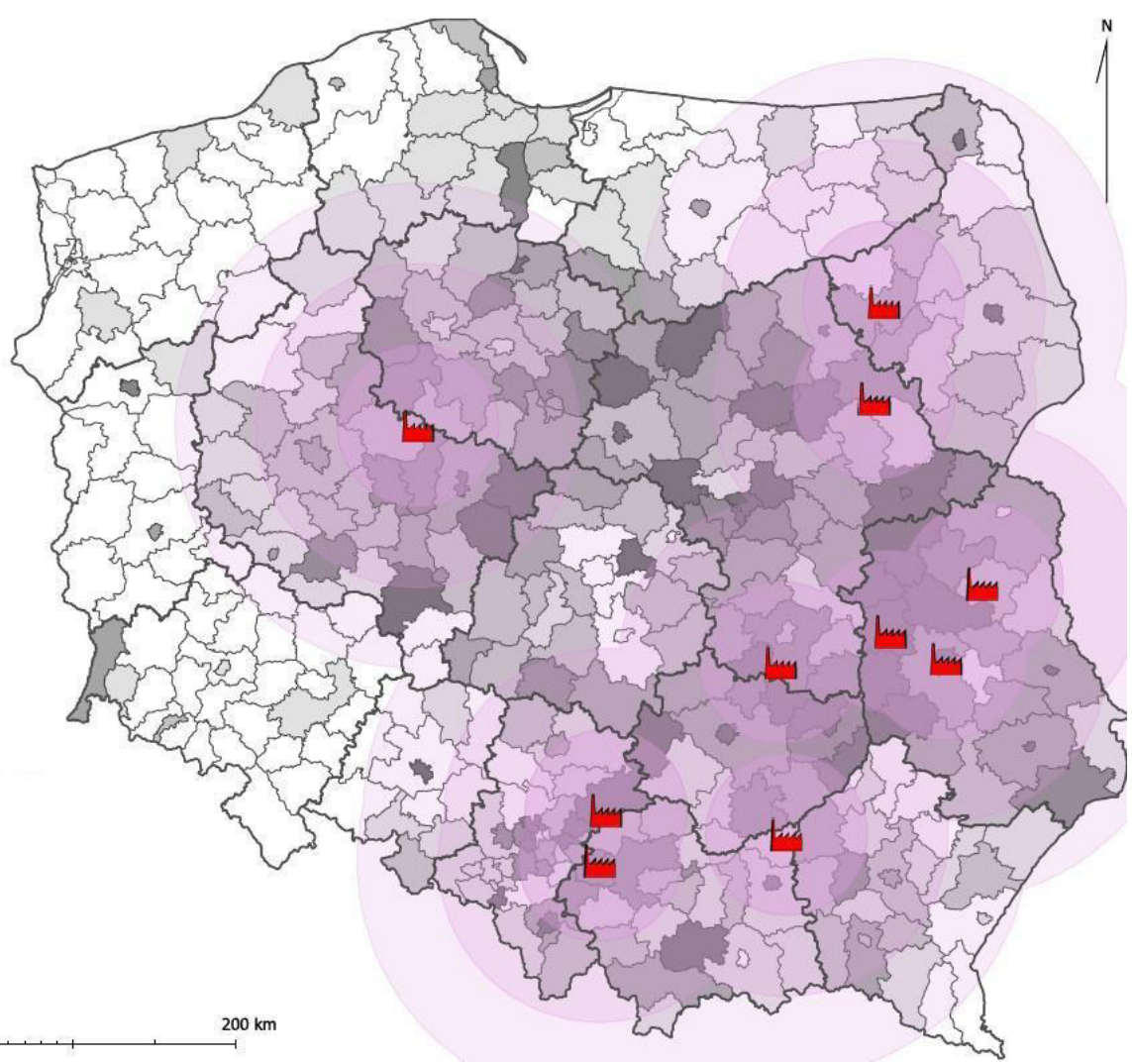

Figure 2. Plants manufacturing asbestos-cement roofing

\section{References}

Act of 19 June 1997 on the prohibition of the use of asbestoscontaining products.

Alleman, JE \& Mossman, BT 1997, 'Asbestos revisited', Scientific American, vol. 277, no. 1, pp. 70-75.

'Asbestos. 2006 Mineral Yearbook' 2007, U.S. Department of the Interior, U.S. Geological Survey.

'Asbestos. 2012 Mineral Yearbook' 2013, U.S. Department of the Interior, U.S. Geological Survey.

Brzozowski, A \& Obmiński, A 2004, 'Gdzie występuje potrzeba zabezpieczania lub usuwania azbestu w Polsce?', Bezpieczeństwo Pracy, no. 4, pp. 11-15.

Collegium Ramazzini 2010, 'Asbestos is still with us: repeat call for a universal ban', Odontology, no. 98, pp. 97-101.

Dunnigan, J 1993, 'Chrysotile asbestos revisited', British Journal of Industrial Medicine, vol. 50, pp. 862-863.

Dyczek, J (ed.) 2005, 'Azbest-bezpieczne postępowanie', conference materials Asbestos and asbestos-containing materials in buildings and structures. Minimizing the risk of emission of fibers during the removal of asbestos-containing materials, Wydawnictwo Naukowe „Akapit”, AGH, Kraków, pp. 77-78.

Hendry, NW 1965, 'The Geology, Occurrences, And Major Uses Of Abestos', Annals of the New York Academy of Sciences, vol. 132, pp. 12-21.

Lee, D \& Selikoff, I 1979, 'Historical background to the asbestos problem', Environmental Research, no. 18(2), pp. 300-314.
Łuniewski, A \& Łuniewski, S 2009, 'Azbest. Historyczne obciążenie z XX wieku', Wydawnictwo Ekonomia i Środowisko, Białystok.

Ordinance of the Minister of Economy of 13 December 2010 on requirements for the use of products containing asbestos and the use and cleaning of plant or equipment, which have been or are being used asbestos-containing products.

Ross, M, Langer, AM, Nord GL, Nolan, RP, Lee, RJ, Van Orden D \& Addison, J 2007, 'The mineral nature of asbestos', Regulatory Toxicology And Pharmacology: RTP [Regul Toxicol Pharmacol], vol. 52 (1 Suppl), pp. 26-30.

Siuta, J 2001, 'Nie tylko w Szczucinie', Ekoprofit, no 2, pp. 6-10. Thompson, S \& Mason, E 2002, 'Asbestos: Mineral and fibers', Chemical Health And Safety, vol. 9, no. 4, pp. 21-23.

Virta, RL 2001, 'Some Facts About Asbestos', USGS Fact Sheet: 012-01. Available from: <http://www.capcoa.org/Docs/noa/ \%5B12\%5D\%20USGS\%20Facts\%20on\%20Asbestos.pdf>. [10 December 2013].

Virta, RL 2002, 'Asbestos: Geology, Mineralogy, Mining, and Uses 2002', USGS Open-File Report: 2002-149. Available from: <http://pubs.usgs.gov/of/2002/of02-149/>. [10 December 2013].

Virta, RL 2006, 'Worldwide asbestos supply and consumption trends from 1900 through 2003', U.S. Geological Survey Circular 1298. Available from: <http://pubs.usgs.gov/ circ/2006/1298/c1298.pdf>. [10 December 2013]. 